\title{
KAZANTZAKIS-UNAMUNO, VOCES EN PROTESTA ${ }^{1}$
}

\author{
Roberto Quiroz Pizarro \\ Universidad de Chile. Chile
}

Resumen: La aproximación de la figura y del pensamiento unamunesco a una de las tempranas obras de Kazantzakis, concretamente Comedia, permite generar un diálogo interesante y visionario entre los autores. Sobre estos intelectuales se observa una "heterodoxia" que los confronta con el espíritu de la época bajo una actitud de protesta ante el abuso de la razón y la quiebra de los discursos totalizantes. Ambos autores buscan una salida por la vía del individuo.

Palabras Clave: Kazantzakis - Unamuno - literatura - filosofía crisis - existencialismo - crítica religiosa - siglo XX

\section{KAZANTZAKIS-UNAMUNO, VOICES IN PROTEST}

Abstract: The approximation to the figure and thought of Unamuno to one of the early works of Kazantzakis, specifically Comedia, allows to generate an interesting dialogue between the authors. In these intellectuals one can observe a "heterodoxy" which confronts them to the spirit of the time under an attitude of protest towards the abuse of reason and the breaking of totalizing discourses. Both authors search a way out by means of the individual.

Key words: Kazantzakis - Unamuno - literature - philosophy crisis - existentialism - religious critique - XXth century

Recibido: 04.04.2014 - Aceptado: 22.05.2015

\footnotetext{
${ }^{1}$ El presente texto es parte de una línea de investigación mayor y en curso, cuya unidad de exploración son los diversos aspectos en torno al pensamiento y la filosofía de Kazantzakis.
} 
Correspondencia: Roberto Quiroz PizArro, alfanamaste@hotmail.com.

Licenciatura y Magister en Filosofía, Universidad de Chile. Doctor ( Universitat Jaume I-Valencià y Universidad de Chile. Académico y Subdirector del Centro de Estudios Griegos Bizantinos y Neohelénicos "Fotios Malleros”, Universidad de Chile.

\section{Cambio de siglo, itinerarios de incertidumbre}

T a actividad intelectual y cultural es la que trae implicancias Lantropológicas que se proyectan por doquier. Basta recordar el nombre de personalidades como Marx, Nietzsche, Freud, Darwin, Einstein, para darse cuenta del impacto de ruptura o disolución de paradigmas planteados, dándole al hombre una condición de reinvención y redescubrimiento de caminos. No parece otra que la historia de la orfandad de los dioses o del hombre huérfano de sentido terrenal que vuelve a sí mismo. Antes de esas personalidades de quiebre ya aludidas, la marcha del pensamiento entre los últimos siglos se apoyaba en diversos gigantes --las creencias religiosas, las ideas del realismo, del naturalismo, de la retroalimentación entre ciencia y economía, las del concepto de "científico" o la confianza en el progreso y la ilustración, o en el mito del eurocentrismo. Sin embargo, en el andar de cambio de siglo habrá un efecto y reacción multifacética de elementos emergentes -simbolismo, decadentismo, marxismo, irracionalismo, vitalismo, nihilismo, fenomenologismo, intuicionismo, emotivismo existencial, relativismo, nacionalismo--, los que de ahora en adelante darán paso a un mundo de incertidumbres, relativismos, irracionalidad y caos. Se produce una sensación de vacío, de desorientación y crítica cultural, una primera bancarrota de la racionalidad in extenso pero aún oculta, no reconocida, y eso obligará a buscar caminos de un cierto refugio a partir de quizá nuevos valores y concepciones de la vida, si acaso 
algo así sea posible después de lo planteado por Nietzsche. A pesar de la complejidad de las cosas, al menos se dará una búsqueda con sello personal, encarnada en autores -Unamuno, Kazantzakis, entre varios-- que ensayan otra razón sintiente, otra racionalidad, o bien una filosofía a escala más humana o que ahora pretenda ir "a las cosas mismas" más que a la razón misma, y menos contaminada de la vieja idea de confeccionar un gran sistema. Se comprenderá que para describir este nuevo mundo variable y polifacético se necesitan metáforas, símbolos, confluencias de opuestos, o el murmullo de lo mítico quizá, o gritos de entraña y no sólo otros recursos abstractos o hiperracionalistas, sino de aquellos que aproximen las caras de la realidad a lo humano demasiado humano también. En consecuencia, ante tal escenario turbulento del cambio y nuevo siglo, se despertará una mirada múltiple, intimista, solitaria, errática y de suyo al borde de no poder escapar de lo que será una especie de salvación personal y filosófica, y ese hálito de búsqueda es lo que se mueve libremente en las obras de Unamuno y Kazantzakis.

Toda la confianza en el entendimiento humano, en el auge cientificista, racionalista, dialéctico, empirista, positivista y de renovado optimismo teórico, va a tener señales de un dramatismo y quiebre de certezas con la oscuridad de los acontecimientos mundiales. Antes de la I Guerra Mundial de 1914 se afirmaba "que las edades pasadas del mundo sólo presentan la historia de la irracionalidad humana y que sólo ahora estamos avanzando hacia la aurora de la razón y hacia el período en que la mente del hombre nacerá de nuevo". Fue una confianza que se vino abajo de manera inquietante. En tal sentido, Unamuno y Kazantzakis, pensadores de transición, sienten toda la incertidumbre de la cultura europea y no comparten el optimismo intelectual que parecía reinar. Creen que se tiene que hacer literatura o filosofar de un modo en que el hombre arrastre consigo todas sus agitaciones humanas, $y$ por ello tomarán la apuesta de que se debe filosofar en primera persona, siendo lo más fieles a ese yo existencialmente iluminado y no solo siguiendo el dictamen de las especulaciones abstractas. 
Hasta hacía poco el criterio de la verdad estaba culturalmente aposentado en la razón, en la racionalidad misma, y también en el dogma de la fe, en la institucionalidad religiosa, pero ahora y con la influencia de pensadores como Nietzsche y otros, se alega que el criterio debe ser la vida.

En gradaciones de experiencias propias y aún como escritores del siglo XX, Unamuno y Kazantzakis mantienen unos lazos con visiones de espíritu dramático y romántico, con la mítica figuración del héroe, preservan una sed de aventuras y una sensibilidad para lo místico y espiritual que entra en claro contraste con "la creciente grisura, normalidad y reglamentación del presente burgués"; en parte, será así porque estos autores chocan con la idea de cosificación y mensurabilidad del mundo; en parte, porque ellos mismos no se cierran a otras posibilidades de profundización en la realidad, y en parte, porque esencialmente les invade un sentimiento metafísico o un grito o una necesidad última que se aloja en la propia conciencia del hombre. En estos autores el misterio del hombre no se podía cerrar definitivamente sobre las formulaciones de unas cuantas verdades de fe, verdades de razón o de hecho, como se lo había pretendido hacer por tantos siglos. Ellos creen que la verdad humana se parece más a una aventura mítica, mística o filosófica, donde lo absoluto se ve como una materia irreductible a palabras o a formulaciones dependientes de la racionalidad. Son más bien videntes que no animales racionales, más románticos que lógicos, más hombres de oráculos que de una explicación metódica. Por eso rechazan una reducción de la vida a lo que no está vivo. A tales autores les parece que la filosofía de la vida rivaliza con el pensamiento científico, mecanicista, esquematizante, matemático, lógico, racionalista y estático. En oposición a ello, ponen

\footnotetext{
${ }^{2}$ Kahler, E. Historia Universal del hombre, FCE, México, 1960, p. 492.

${ }^{3}$ En efecto, en sus primeros y breves escritos, Kazantzakis manifiesta una postura cuestionadora, La enfermedad del siglo y ¿Está en bancarrota la ciencia?, El primer maestro, Comedia. En años vecinos (1912-1913) encontramos el libro de Unamuno, Del sentimiento trágico de la existencia, una apasionada protesta que se mueve entre los cánones de la fe y la razón. Otras obras que anteceden su tonicidad reflexiva son En torno al casticismo (1895), Mi religión y otros ensayos (1910), Soliloquios y conversaciones (1911).
} 
de relieve el valor de lo irracional, lo singular, lo interior, lo anímico, lo dinámico, lo vivencial, lo vital, lo natural, lo existencial ${ }^{3}$.

\section{Parentesco intelectual}

Nikos Kazantzakis tuvo la posibilidad de conocer en Salamanca a Miguel de Unamuno meses antes de fallecer. Fue una visita en plena Guerra civil española, entre labores de periodista y hombre de cultura. Más allá del encuentro en sí, a estos personajes se les podría dar un calificativo común en vista de la obra que presentan, de los caminos sinuosos y no rectilíneos que plasmaron y del ímpetu filosófico que se respira en su arte, todo lo cual les hace ver como los exponentes de una "heterodoxia literaria"4. A su manera la obra de cada uno comparte pinceladas de vitalismo, una actitud de protesta irracional, un romanticismo y estoicismo trágico, una sensibilidad para lo místico y la no menos inquietud de una atenta mirada "racional" --entre comillas-- para procesar la vida. Sin embargo, era una racionalidad de apoyo, un ojo más, pero también un peso muerto que a menudo les ahogaba, ya que ambos autores vacilaban en permitir que la "razón" se conviertiera en el centro y tiranía de lo humano. En un primer sentido, estos autores corrieron el peligro de enfrentar lo que se suponía era tender un diálogo entre la obra "literaria" personal y las corrientes dominantes y polémicas de la tradición europea y del pensamiento. Por eso el lector ve que sus literaturas llevan a ese gesto donde se interroga y problematiza el cosmos según esa misma costumbre de los filósofos fundadores.

Uno y otro son hijos de una extensa tradición cultural, ambos logran ser testigos de una época convulsionada y no ausente de conflictos, y además, por cuenta propia, acaban imaginando la posibilidad de explorar conceptos y asentamientos ideológicos que les permitan ampliar el sentido de una literatura que pasa a ser vista mucho más que como ficción y escenarios de estética. Les posee

\footnotetext{
${ }^{4}$ El presente trabajo se alinea en la dirección temática de otros artículos en torno al esbozo filosófico de Kazantzakis y de las aristas hermenéuticas que nos proporciona una obra como Comedia. En tal sentido, cada trabajo implica un eslabón de conjunto.
} 
el impulso de "escritores heterodoxos" bajo el movimiento de una restrictiva literatura con sentido crítico y en los bordes mismos de una escritura comprometida filosóficamente en develar los espacios penumbrosos de la siempre "realidad humana". Así y en las manos de la literatura, estos autores cruzaron a otras fronteras donde la condición humana no pierde sino que incrementa su complejidad vital y paradójica existencia, consumándose en ellos el esfuerzo no menor de encauzar su arte sobre formas en las que la filosofía volviera a la vida de nuevo. Tras siglos del hiperracionalismo en su variedad de fenómenos, o entre tanta dogmática de fe y costumbrismos, la vida en su dimensión de misterio había quedado plana, deshabitada, carente de nuevos mitos y desafíos.

Una de esas metáforas en que mejor resuena la actitud agónica existencialista, antiintelectual y de nutrido contacto con la experiencia vital y personal, es la sentencia unamunesca del "hombre de carne y hueso", la que también nos parece una sentencia militante en el corpus kazantzakista que protesta y dialoga con la filosofía misma. En lenguaje propio y con afinidades transversales a las del escritor salmantino, Kazantzakis hace notar al lector que su literatura no parte ni lleva consigo la finalidad de arrimarse a la figura del hombre abstracto ni tampoco la de ampararse en los modelos de una intelectualidad hegemónica ni va tras los postulados de un sujeto soberano de la razón. Más bien recurre a imágenes dramáticas - un grito, un rastro de sangre, el fuego que devora las entrañas, la dolorosa liberación metamórfica del hombre, el sentir abismático de la muerte, del destino o de una salvación desconocida, o ya el Gólgota de la existencialidad-, mediante las cuales el lector llega siendo guiado a ese núcleo de una literatura pasional, vital, existencial, trágica, irracional, desbordante, misteriosa, romántica, con sensibilidad oculta para lo místico.

En tales huellas impresas a las obras de estos autores, tal como las anteriores del "hombre de carne y hueso" o del Gólgota ensangrentado, es como la literatura adquiere un soplo filosófico, una demanda 
antropológica, y así de este modo el lector pasa casi naturalmente a sentirse raptado bajo el reflejo de su propio "ser hombre", y a ser uno más en el continuum vital que lo reclama como "hombre de carne y hueso". En tal sentido parece engañosa la obra de Kazantzakis porque su espíritu literario siempre va a estar en acecho de las experiencias límites y del vértigo intelectual que mantiene bajo tensión a los filósofos en su duelo con la verdad. En parentesco mutuo y directo son hombres de letras pero aguijoneados por las angustias filosóficas y del pensamiento en transgresión de los fenómenos aislados y del velo de las apariencias. Lo que se vislumbra ante el "hombre de carne y hueso" es la nada, el absurdo, el sinsentido, lo irracional, la angustia existencial, la finitud, la angulosa realidad inasible para la razón, la nostalgia del absoluto, y por eso hay sobre ellos un estigma, una "meditatio mortis", una búsqueda de caminos y de trascendencia, un combate de espíritu y materia, de apariencia y realidad. A ese fondo "misterioso" aluden las líneas de estos autores, lo cual puede interpretarse también como una aproximación integradora entre literatura y filosofía.

\section{¿Escritores de ficción?}

Al recorrer las territorialidades literarias de sus obras o escanciando los fragmentos de sus textos conocidos, uno llega a cierta confusión sobre los autores: Unamuno, Kazantzakis, ¿filósofos encubiertos? ¿pensadores fronterizos? ¿poetas que filosofan? Uno puede tener su propia opinión o preferencia intelectual, y especialmente tener a la vista otras fuentes como la voz autorizada de la intelectualidad, por ejemplo, o revisar diversa documentación histórica, diccionarios, revistas, enciclopedias ${ }^{5}$.

Una primera señal que despierta curiosidad es ver que tales fuentes griegas no tienen la misma mirada para referirse a Kazantzakis, pues

\footnotetext{
${ }^{5}$ Por ejemplo, en cuanto al mundo literario de Nikos Kazantzakis resulta interesante tener en consideración la Gran Enciclopedia Griega de Pablo Drandakis, de la casa Editorial Fénix, 2a edición, complementada, de 1930, Atenas. También la Gran Enciclopedia de la Literatura Neohelénica. Del siglo X hasta hoy, tomo VII, de la casa Editorial Jaris Patsis, cuyo artículo está a cargo de Manolis Yalurakis "Kazantzakis", de 1968, Atenas.
} 
algunas lo categorizan de poeta, prosista, novelista, dramaturgo, ensayista, periodista, mientras que otros críticos lo insertan entre uno más de los escritores que filosofan a su manera, pero con el resguardo debido de no situarlo como un gran filósofo de profesión. Sin embargo aquí lo importante pasa a ser esa acreditación filosófica más que saber si lo que hace Kazantzakis sigue los patrones canónicos del discurso estrictamente filosófico o bajo una escuela doctrinaria. Así entonces y mediante las fuentes documentadas sobre Kazantzakis, uno puede pensar que lo mismo puede ocurrir dentro de la opinión que se tiene de otro autor o ámbito, como por ejemplo, los posibles desajustes de imagen en otras latitudes, sería tal como el caso de un diccionario británico en donde dijera de Unamuno es filósofo y que por su lado, las fuentes hispanas no tengan al respecto un consenso final. Lo que se pone en evidencia en estos casos de "escritores heterodoxos" es la ambigüedad de fronteras y donde la opinión crítica o el juicio temporal pueden cambiar y redefinirse.

De acuerdo a lo anterior entonces, se hace presente el hecho de que no es tan infrecuente que las fronteras o imágenes ideológicas de un escritor puedan depender de espectros y conexiones no planificadas en una especie de extrañeza o marcas que provoca y esconde la propia lectura, el contacto directo con la obra a la par de las opiniones literarias que se tienen como tal. Vamos hacia el texto, hacia tal obra premunidos de que se trata de novela, de un fragmento teatral, de una prosa estética, pero la supuesta ficción germina en su propia lectura y parece convertirse en más cosas a la vez, en una potente materia de realidad poética o verdad filosófica, en un punto de encuentro con algo que nos parece muy real en tanto hombres y no sólo animales racionales. Así sucede con algunas obras de Kazantzakis como El primer maestro, Comedia, Ascesis, Odisea, Carta al Greco, Buda, Cristo, textos que desde su textura y formalidad literaria nos invitan a filosofar heterodoxamente por cuenta propia, mostrando así las potencialidades que encierran y ante las cuales el lector queda fascinado y a merced de una lucidez antropológica y existencial propia de filósofos. 
Por otro lado y en una amplitud de observación, podemos intentar reunir a Kazantzakis y Unamuno en una suerte de situación paralela y de parentesco, y traer a colación una sugestiva opinión del filósofo español Julián Marías en relación a su compatriota. Marías se refiere al escritor de Salamanca en estos términos, “¿qué tiene que ver Unamuno con la filosofía? Hemos visto que su preocupación tenía un fondo coincidente con el problema filosófico, en especial tal como Unamuno concibe éste; vimos también que, a partir de ello, la obra de Unamuno no es sensu stricto filosófica; hemos interpretado, sin embargo, lo más sustantivo de su obra como un esfuerzo de extraño perfil por alcanzar un conocimiento afín a la filosofía". Muy importante es lo que apunta Marías acerca de que habría una preocupación filosófica desbordante de lo que aparenta su materia natural que es la literatura en general: "Pero no conviene olvidar que los libros de Unamuno figuran por derecho propio en la literatura. Sus géneros literarios son principalmente, junto al ensayo, la poesía y la novela, y también el drama [...] Y no se crea que constituyen la obra literaria de Unamuno, junto a otra que pudiera ser, por ejemplo, filosófica, sino que hay la más perfecta unidad en toda ella. Por esto se ha dicho, con plena razón, que todo en Unamuno es poesía, y que hay honda relación entre Del sentimiento trágico de la vida y El Cristo de Velásquez; pero acaso se podría también decir, con no menor razón, que toda la obra de Unamuno excede y trasciende de la poesía y de la literatura en general"'.

El propio Marías desliza la toma de razón de ese extraño fenómeno de fronteras abiertas, pues asumiendo la situación de que se comienza a leer literatura ocurre de pronto que se arriba a terrenos de pensamiento, a tensiones intelectuales y humanas. Tal es el punto de vista que admite las variaciones en el tiempo, y es el caso de manuales contemporáneos más abiertos en reconocer el

\footnotetext{
${ }^{6}$ Marías, J.: El existencialismo en España, versión digital, p. 91. Hay antecedentes de varios ensayos que Marías le dedica a Unamuno, algunos no publicados en su tiempo, como "La obra de Unamuno, un problema filosófico", incluido en La escuela de Madrid, Revista de Occidente, 1959, trabajo que por cierto recoge varios artículos más.
} 
polémico carácter dual de lo filosófico y literario en algunos autores. Bajo una situación equivalente lo señala J. Antonio Pérez Rioja en su Diccionario Literario Universal ${ }^{7}$, quien alude a Kazantzakis en estos términos: "escritor de difícil encasillamiento, puede afirmarse que la novela filosófica alcanza en él su más alta expresión, ya que en prosa desarrolla las tesis de su propia obra poética”.

Por tanto una consideración que hay que tener presente en estos autores de letras es que no tienen la preocupación de darle forma filosófica a sus escrituras, sintiéndose libres del uso de un lenguaje tecnicista y de materia prima que sea propio de la academia de los filósofos. Más bien se oyen las voces de la literatura pero interpretando problemáticas humanas y filosóficas. Esto puede verse como un gesto intelectual en el que se da a entender que se dejan de lado las "filosoferías", lenguajeos y malabarismos conceptuales tan recurrentes entre las escuelas de rigor filosófico. Al fijarnos en estos autores -Unamuno y Kazantzakis - uno puede vaticinar que ellos han desarrollado una especie de pensamiento filosófico para hombres y no para teóricos de la razón. Se busca más una conciencia de las realidades que no una racionalización de las mismas. No es matemática conceptual de sistemas sino urdimbre de voces dispersas en el tiempo lo que se lee en tales autores. Eso explicaría que la lectura de sus obras emana una radiación no frontalmente filosófica o racionalista sino más bien oblicua, etérea, metafórica o como encarnación del propio existir humano.

\section{Una lectura compartida}

Tenemos noticia de que ambos autores hicieron mención de una frase que fue de mucha conmoción en su momento. El hecho no parece azaroso como se supondría sin más, sino que apuntaría a una sensibilidad intelectual que los emparenta en esa "heterodoxia literaria" ya mencionada. Kazantzakis fue el primero que documenta su lectura con esa fuente en común, mientras que Unamuno lo hace

\footnotetext{
${ }^{7}$ J. Antonio Pérez Rioja, Diccionario Literario Universal, Editorial Tecnos, Madrid, 1977, p. 265.
} 
unos años después, no muchos. La referencia a ese texto da la idea de que ambos autores están con esa mirada crítica hacia la ciencia, y que algo vieron en común, o que sospechan que tras la tecnicidad moderna, el positivismo del laboratorio o la ciencia pura, no hay esa liberación prometida a los hombres ante su destino trágico. La condición científica donde ellos escriben corresponde a la misma época en que todos tenían la vaga sensación de que el "mundo está al alcance de la mano", y que la ciencia y la razón habían triunfado.

Años antes había sido famosa la polémica que sostuvo en $1897 \mathrm{~F}$. Brunetière $^{8}$ con el célebre químico Berthelot a propósito de la llamada "bancarrota de la ciencia”. Sostenía aquél que la ciencia al prometer soluciones para todos los problemas tanto de orden natural como del sobrenatural, había caído en el más ridículo de los descréditos. ¿De dónde venimos? ¿a dónde vamos? ¿cómo vivir la vida?, es lo que se preguntaba Brunetière, y al respecto afirmaba que "ni los telescopios que sondean el espacio sin límites, ni los microscopios que acechan el latido inicial de la vida en lo infinitamente pequeño, habían podido descifrar el enigma supremo".

Kazantzakis comenta brevemente la discusión con la ciencia en un pequeño ensayo perdido en medio de su polifacética obra literaria. Se trataría de un escrito de 1909. La elocuencia del título es palmaria “Está en bancarrota la ciencia?”. Ha tomado el nombre

${ }^{8}$ F. Brunetière (Tolón, 1849 - París, 1906). Crítico literario francés, profesor ("maître de conférences) desde 1886 en la École Normale Supérieure. Se le conoció como un polémico, agudo y controversial escritor de amplios temas culturales, el que a partir de 1875 colaboró en la Revue des Deux Mondes, y que dirigió desde 1895 hasta su muerte. Este autor publicó un artículo de gran repercusión en el que planteaba la caída de la ciencia cuando había gran optimismo científico. Su argumento era que la ciencia no había cumplido sus promesas tal como otras ramas, la medicina, que parecían haber ganado eficacia. Por el contrario, la ciencia no había hecho mejor a la humanidad, ni tenido un efecto beneficioso en la política, ni resuelto los grandes misterios de la naturaleza ni revelado el destino del ser humano. Las palabras del autor francés escandalizaron a toda Europa y a los que veían en la ciencia la única fuente de todo conocimiento y progreso. Se organizó también una respuesta enérgica. Sobre todo por parte de uno de los sabios más célebres de la época, M. Berthelot, que respondió directamente a F. Brunetière que "el triunfo universal de la ciencia llegará a garantizar a los hombres la máxima felicidad y moralidad”. 
de la declaración hecha por Brunetière, en la que se argumentó que la ciencia como fuerza ética y destino humano está en evidente bancarrota. El escenario científico de entonces era una toma de posiciones, unos que como Poincaré ponen en duda el valor de la ciencia --con el relativismo de la verdad matemática o zonas de incomensurabilidad--, y otros que pregonan la seriedad de esta disciplina. Frente a ese panorama crítico Kazantzakis dice que la ciencia está, en efecto, en bancarrota si esperamos que ella nos conduzca hacia la felicidad y el progreso humano, es decir, si nuestra necesidad está encaminada a obtener propósitos y resultados éticos y metafísicos. Sin embargo, el propio autor cretense añade un interesante matiz de incertidumbre a sus palabras, al considerar que si la enfocamos estéticamente como "el maravilloso instrumento [...] mediante el cual el espectáculo de la vida se extiende y cambia[...]", entonces la ciencia puede estar más cerca del hombre. Esto sería mirarla bajo otro espíritu, explorarla estética y simbólicamente y no bajo el exclusivo plano epistemológico de las verdades científicas o absolutas, entendidas en ese tiempo.

Por otro lado, a pocos años y en un estremecedor ensayo de 1912, Unamuno refleja inquietudes y cuestionamientos respecto de la ciencia. Más aún, el escritor español se refiere al mismo revuelo de la polémica causada por la frase impertinente hacia la ciencia y la razón. Unamuno dice que la ciencia es más extraña que la filosofía, pues cumple un fin más objetivo, "más fuera de nosotros", y agrega un juicio lapidario respecto al colapso que experimenta el mundo científico: "no sé por qué tanta gente se escandalizó o hizo que se escandalizaba cuando Brunetière volvió a proclamar la bancarrota de la ciencia. Porque la ciencia, en cuanto sustitutiva de la religión, y la razón, en cuanto sustitutiva de la fe, ha fracasado siempre. La ciencia podrá satisfacer, y de hecho satisface en una medida creciente, nuestras crecientes necesidades lógicas o mentales, nuestro anhelo de saber y conocer la verdad; pero la ciencia no satisface nuestras necesidades afectivas y volitivas, nuestra hambre de inmortalidad, y lejos de satisfacerla,

${ }^{9}$ M. de Unamuno.: (1913) Del sentimiento trágico de la vida, Madrid: Renacimiento, p. 105-106. 
la contradice. La verdad racional y la vida están en contraposición"'. En otra referencia, el filósofo español habla del siglo XIX como una etapa de vulgarización de la ciencia, y vuelve a mencionar a Brunetière, "todo esto llevó a Brunetière a proclamar la bancarrota de la ciencia, y esa ciencia o lo que fuere, bancarroteó en efecto"10.

Con estas breves referencias se hace posible de ver que estos autores no quisieron que las fronteras del hombre acabaran allí donde la ciencia y la razón decían la última palabra. No hay que considerar estas alusiones de Unamuno y de Kazantzakis respecto a la proclama de Brunetière como una curiosa casualidad. Al contrario, es un hecho que los vincula en sus aspiraciones filosóficas y en el desenvolvimiento de una sensibilidad antirracionalista, antipositivista y de sus implicancias en juego. Esa desconfianza sobre la razón a secas denota otros énfasis como el humanista, existencialista, vitalista, irracionalista, teológico, metafísico, ético, los cuales se fueron haciendo parte en sus proclamas y alegatos en favor de una manera de filosofar propia de ellos, lo cual es tanto como decir de una filosofía en primera persona y como "hombres de carne y hueso"11.

\section{La actitud existencialista}

Surgido como una reacción contra el exagerado racionalismo acumulativo en la cultura europea y sus crisis - pero con carta de natalidad en la postguerra--, el existencialismo más bien es un estado de espíritu que una escuela de principios bien definidos. La postura existencialista es una denuncia cifrada hacia la decadencia de la

\footnotetext{
${ }^{10}$ Ibídem, p. 291.

${ }^{11}$ Por su lado, Kazantzakis y Unamuno hicieron una lectura de Brunètiere como demarcación de fe, ciencia y de una amplitud filosófica respecto de una sola mirada científico empírica del mundo. Sin embargo, en base a otros escritos religiosos a Brunètiere se le puede dar otra interpretación teológica como la que presenta el obispo español, A. González Montes, diciendo que el autor francés traza una línea divisoria entre ciencia y fe, en donde ni la primera como tal ni la "metafísica racional pueden alcanzar el secreto de la vida concreta en su determinación propia”. Entonces, más que una cristología que sirva de fundamentación al dogma y al misterio humano, lo que hay que intentar es una eclesiología que aporte un valor moral para la humanidad y cuya última realidad divina viene a estar dada y ser comprensible en esa trascendencia de la que el hombre es portador.
} 
vida humana y un descentramiento de la razón -más precisamente, un tipo de versión de ella. El individuo de carne y hueso se vuelve ahora el protagonista sobre lo que se filosofa, y en torno a él se analiza su posición, su existencia vital, su angustia, sus inquietudes, su trágica temporalidad, su muerte, su libertad compleja, sus crisis. En una palabra, se busca tanto un sentido a escala humana pero sin ocultar la posibilidad del sinsentido existencial, dándose aperturas en ambos horizontes, unos más libres y otros en alianza con el pensamiento tradicional.

Entre los especialista y cultivadores de la disciplina se ha dicho que el existencialismo es una filosofía en primera persona. "En la nueva filosofía, la conciencia deja de ser contempladora, para ser actora. El nuevo camino será, en consecuencia, no el de las sumas o tratados, sino el de la literatura que pone en existencia concepciones sobre la vida" 12 . Con el sentimiento agónico unamunesco y con una actitud de rebeldía y encaramiento en Kazantzakis, se prepara el gran debate de fondo en ellos, cambiando la mirada en una dirección que va hacia "el hombre de carne y hueso" y de su "itinerario existencial". El giro literario de estos autores apuesta por una revaloración del individuo y su interrelación con la realidad. Se vislumbra por tanto, una propuesta de filosofar desde el punto de vista del actor, en lugar de hacerlo como ha sido frecuente, desde el punto de vista del espectador ${ }^{13}$. Allen contrapone la actitud impersonal del científico con los esfuerzos interiores de quien filosofa desde su propia problemática. Esto significa varias cosas. Primero, que el problema se presenta ante el filósofo como algo emanado de su propia existencia personal, de su raíz individual, de quien busca esclarecer su destino vital. Segundo, que el problema es de interés vital para él como ser humano, no simplemente a consecuencia de circunstancias accidentales. En tercer lugar, el criterio de filosofar desde el punto

${ }^{12}$ C. García Álvarez. (1997) Byzantion Nea Hellás, "Dos itinerarios espirituales: Miguel de Unamuno y Kazantzakis". Santiago: LOM Editores, n 16, p. 76.

${ }^{13}$ Cf., el planteamiento de E. L. Allen (1953) Existentialism from Within, New York: Macmillan. 
de vista del actor, del individuo en sí, impide toda resolución del problema que haga abstracción de uno mismo y de sus implicaciones, y adopte por ejemplo, la perspectiva del absoluto -Dios, la nada u otro concepto derivado--, en la que el individuo como tal se conciba como un ser sin importancia.

Digamos que si no se concede al movimiento existencialista un significado demasiado restringido, demasiado vinculado al modo de pensamiento de una época determinada y a los remolinos sociales que agitaban la conciencia de aquella época, entonces, podemos apreciar interesantes líneas de parentesco o filiación con el talante vitalista, existencialista e irracionalista, presente en los laberintos literarios de tales autores. Quizá habría que plantearlo de otra manera: suponer que en estos autores había una tendencia "filosófica" inherente a sus naturalezas y que se expresa bajo un espectro de sensibilidad humana, la cual encontró viva expresión en todas aquellas líneas de pensamiento que les conocemos. En un cierto sentido, también se podría hablar de precursores, o de espíritus que tuvieron puntos de contacto con el existencialismo avant la lettre. Para Kazantzakis hemos dado una lectura existencialista avalada en una temprana $\mathrm{obra}^{14}$. ¿Qué hacer en el caso de Unamuno? Se dispone de ciertas opiniones a favor: "se puede considerar a Unamuno como el descubridor de Kierkegaard, cuando éste era todavía un desconocido en Europa, y por ello ha de verse en él también un precursor de los movimientos filosóficos, particularmente del existencialismo"15. Es una opinión muy directa que aprecia la obra unamunesca más allá del terreno oficial de la literatura. En fin, desde diversos ángulos se le reconoce un valor especial a Unamuno, "porque los demás pensadores existencialistas no han abandonado totalmente la razón como método de resolver los enigmas metafísicos. Aunque reconocen la existencia del reino de lo irracional, tanto en el hombre como en el universo, continúan

\footnotetext{
${ }^{14}$ Cf. lo que se ha planteado focalizadamente en "Kazantzakis ¿existenicalista avant la lettre?". R. Quiroz P. (2003): Nikos Kazantzakis Impronptu filosófico, Santiago: LOM Ediciones. ${ }^{15}$ J. Hirschberger.: (1990) Historia de la Filosofía, Barcelona: Editorial Herder, II, p. 506.

${ }^{16}$ A. Machado, pone de relieve esa circunstancia cuando indica que "de todos los grandes pensadores que hicieron de la muerte tema esencial de sus meditaciones, fue Unamuno el que menos habló de resignarse a ella [...] La crítica, sin embargo, deberá señalar que,
} 
debatiendo este punto y tanteando sistemas para recurrir a la lógica más que a la poesía"16. Asimismo, "lo que en el lenguaje místico se denomina alma, en la filosofía se llama: existencia”; y agregaríamos esto: que en el caso de Unamuno se llamaría "la existencia del hombre de carne y hueso". Tal es el núcleo desde donde se ilumina nuestra consideración de que hay voces en protesta y no tan lejanas entre Unamuno y Kazantzakis.

A juicio de Unamuno no se puede comenzar a filosofar con omisión del propio hombre como punto de partida. "Si un filósofo no es un hombre es todo menos un filósofo" ${ }^{17}$. He aquí una perspectiva vital que no destierra la condición humana como tal, pues el hombre de carne y hueso anida en nuestra entraña. "La filosofía es un producto humano de cada filósofo y cada filosofo es un hombre de carne y hueso que se dirige a otros hombres de carne y hueso". Es una de las proclamas que más enfatizan el carácter humano de la filosofía y de la terrenal condición del filósofo en el sentir unamuniano. Aquel horizonte inamovible que se mantiene tras el pensamiento de los hombres es su punto de mira: el existir humano. Las ideas como ideas se rompen ante la sustancia de la vida, pues lo que verdaderamente importa es nuestra vida, nuestra muerte, y "lo que ella es por debajo de la maraña de ideas en que se envuelve: carne, hueso, congoja, sufrimiento y esperanza"18. Se aprecia en el trasfondo -más encubiertamente y sólo explícita en momentos particulares- que tras la literatura de estos autores aludidos, Unamuno y Kazantzakis, se va dando una crítica a la filosofía de los filósofos, siempre prestos a adscribir fórmulas abstractas que hablan "del" hombre y de "la" vida, pero que se olvidan de la concretud de "sus" mismas vidas o de la de otro cualquiera a su lado. Estos hombres vitalistas, sensibles, metarracionalistas, filosofan a partir de las entrañas del hombre de carne y hueso. Son hombres

coincidiendo con los últimos años de Unamuno, renace en Europa toda una metafísica existencialista, profundamente humana, que tiene a Unamuno no sólo entre sus adeptos, sino también -digámoslo sin rebozo- entre sus precursores". En Juan de Mairena (1949).

Buenos Aires: Losada, p. 174 y ss.

${ }^{17}$ M. de Unamuno, op.cit., p. 19.

${ }^{18}$ J. Ferrater M.: (1944) Unamuno, bosquejo de una filosofía. Buenos Aires: Losada, p. 38. 
sacudidos por enigmas radicales y vivientes: hombres que oscilan entre "la voluntad de ser y la sospecha de que puede dejar de ser, el sentimiento y el pensamiento, la fe y la duda, la seguridad y la incertidumbre, la esperanza y la desesperación, el corazón y la cabeza, la vida y la lógica"19, lo cual viene a ser en lenguaje de filósofos, la extrema tensión entre lo racional y lo irracional, lo vital y lo teórico, lo efímero y la seducción de lo absoluto.

\section{El nuevo mito del "hombre de carne y hueso"}

El hombre no tiene más remedio que tambalearse, y como hombre que es está en el ojo del torbellino de la vida, vive comprometido con su existencia palpitante de abismos que la razón deja de lado. "El hombre de carne y hueso agitado por la tragedia no es el que ha huido de la sinrazón y del mundo de los sueños para acogerse a la luz --implacable, pero a su modo consoladora-- de la razón, mas tampoco el que ha escapado del universo racional para habitar el cosmos --estremecido y cálido-- de la fe: es el que oscila perpetuamente entre uno y otro; más aún el que está constituido por el uno y por el otro" ${ }^{20}$.

El siguiente comentario puede aplicarse a ambos: "El error de la filosofía, de toda filosofía, ha sido desatender tales realidades o intentar 'explicarlas' en vez de sentirlas, esto es, de abrazarse a ellas. En medio de su vorágine estamos nosotros, los hombres, y sólo gracias a ellas vislumbra cada uno de nosotros que cuando hemos dado cuenta de todo nos queda todavía lo único que realmente importa: mí verdad o tu verdad"21. Hablar de mi verdad es ya el inicio de la confesión, cosa que Kazantzakis hace, pues no sólo pretende estrujar la reseca corteza lógica, sino forjar palabras que beban de la propia vida o sangre existencial del hombre. En efecto, expresa que "la creación no es sino la forma más elevada y más exacta de autoconfesión" ${ }^{22}$. Esta autoconfesión no es un accidental

${ }^{19}$ Ibídem, p. 43. 310.

${ }^{20}$ Unamuno, M. (1913). Del sentimiento trágico de la vida, Madrid: Renacimiento. p. 45.

${ }^{21}$ Ibídem, p. 40.

${ }^{22}$ N. Kazantzakis.: (1998) Viajando España. Trad. Guadalupe Flores L. Madrid: Ediciones Clásicas, p. 7. 
acto, una contingencia más, un relativismo literario del momento, o una infidencia que rompe el cascarón del yo; por el contrario, lo confesional es una verdad subjetiva, una certidumbre personal que emana del "hombre de carne y hueso". "Creo que si soy capaz de captar todo esto en palabras podré ayudar a aliviar la agonía de otros espíritus afines que sigan el mismo camino.

Deseo que esta confesión sea una buena acción. No pretendo otra cosa. Porque no estoy haciendo arte. Sólo estoy dejando llorar a mi propio corazón"23.

Y en otra parte señala: "Sé que lo que escribo nunca será de un arte consumado, pues mi intención es tratar de superar los límites del arte[...] A medida que escribía sentía más profundamente que al escribir no me esforzaba en crear la belleza sino la redención" 24 . Las palabras que son la materia prima de estas literaturas o filosofías confesionales, no sólo quieren expresar una verdad vital; en cierto sentido la viven, son una verdad existencial, "sangre del espíritu".

Luego de estos fragmentos proporcionados por Unamuno y Kazantzakis, nos debe quedar en claro una cosa, que ellos escriben a partir de una resonancia personal, de un grito del yo que se adentra trágicamente en su intimidad y no a partir de un fundamento abstracto, teórico. Parten de la existencia, toman sus instrumentos humanos de las vivencias abisales del alma, de la intimidad. Asimismo, Unamuno enfatiza palpablemente el plano del hombre concreto. En sus meditaciones vemos ciertas palabras claves simbólicas, como: "entrañas", íntimo, huesos, entresijos, oculto, abismo, fondo, profundidad, insondable, alma. Algo equivalente sucede con el mundo literario de Kazantzakis, donde hallamos palabras que denotan un tono existencial y vitalista, imágenes que se repiten bastante: sangre, corazón, alma, lucha, voz, entrañas, grito, deber, desesperación, vida, rostro, alegría, dolor. Sin ir más lejos, en

\footnotetext{
${ }^{23}$ N. Kazantzakis. : (1985) España dos rostros. Trad. Joaquín Maestre. Buenos Aires: Ediciones Carlos Lohlé, p. 8.

${ }^{24}$ N. Kazantzakis.: (1968) Carta al Greco, O.S. Barcelona: Planeta, t. III, p. 553.
} 
el caso del escritor griego, uno de sus libros comienza así: "Recojo mis herramientas: la vista, el oído, el olfato, el tacto, el espíritu. Ha caído la tarde, termina la jornada de trabajo, vuelvo a mi casa como el topo a la tierra". Son palabras que corporizan la realidad concreta del hombre, las que no se refieren a "cosas en sî", como gusta a los filósofos. Hay una cierta tangibilidad en ellas, cierta pulsación vital, un sentido terrenal nietzscheico. En Unamuno la realidad emana precisamente de las "entrañas palpitantes", de "lo contradictorio", erupciones que son de la misma esencia trágica de la vida. En consecuencia, son hombres dolientes y trágicos que no se dejan encajonar en las categorías de una razón universal abstracta o en la "pura" cogitación cartesianista de los filósofos. Ellos dirían que la poesía es el alma de las cosas, no la razón.

La verdad racional les parece una quimera, un fantasma: “ $i S a b e r$ por saber! ¡La verdad por la verdad! Eso es inhumano"25, comenta el autor español. Y a su vez Kazantzakis nos señala: "Escribía y me sentía orgulloso [...] hacía lo que quería, transformaba la realidad [...] mezclaba inextricablemente verdades y mentiras, ya no había más verdades y mentiras, todo era una arcilla blanda que yo modelaba, deshacía, según las inspiraciones de mi capricho, libremente [...]". Eso es lo que ellos ven, que la propia verdad está teñida de una pasión, de un compromiso vital con uno mismo, y que ella es una experiencia más parecida a una zarza ardiente de revelamientos que de otra cosa.

Unamuno afirma, "¿qué es verdad? Verdad es lo que se cree de todo corazón y con toda el alma. ¿Y qué es creer algo de todo corazón y con toda el alma? Obrar conforme a ello"26. La verdad es lo que nos mueve ahora, como hombres de carne y hueso, lo que nos provoca a actuar, ya que "el criterio de la verdad es la vida, no la coherencia lógica, que solamente lo es del entendimiento" 27 . La verdad es un

\footnotetext{
${ }^{25}$ M. de Unamuno, op. cit. p. 33.

${ }^{26}$ M. de Unamuno, O. C., ¿Qué es verdad? Edición digital: Ediciones de la Fundación J. A. de Castro (2007): Ensayos. Madrid, vol. VIII. p. 918.

${ }^{27}$ M. de Unamuno, O. C., Vida de Don Quijote, Edición digital: Ediciones de la Fundación J. A. de Castro (2006): Ensayos. Madrid, vol. X, p. 206.
} 
acto proclamado y vivido ahora, en lo que se hace; una partícula que arrastra nuestro presente: "Y es que hay verdades muertas y verdades vivas, o mejor dicho, [...] hay quienes reciben ciertas verdades como cosa muerta, puramente teórica, y que en nada les vivifica el espíritu"28. Con ello no es la verdad una adherencia mecánica o refleja, es una conciencia despierta, un desgarramiento vital existencial, no un cadáver conceptual.

"La congoja del espíritu es la puerta de la verdad sustancial. Sufre para que creas y creyendo vivas...La verdad es lo que hace vivir, no lo que hace pensar..." ${ }^{29}$.

Aquí, en la filosofía tradicional, pensar es un equivalente de manipular intelectualmente algo. Manipulación que en ningún caso alcanza a ser experimentación profunda como el grito ensangrentado de Kazantzakis o la verdad subjetiva unamunesca: "De lo que hay que huir es de la insinceridad y de la mentira" Nada más lejos de la verdad vital-existencial que la frivolidad, la superficialidad o la vanidad del discurrir intelectual. El hombre puede usar la noción de verdadero o falso en relación a fenómenos del mundo, a cuestiones de cálculo, a experiencias científicas pero ello no agota la unicidad radical de su yo, de su conciencia propia. Para llegar a una verdad hay que atreverse a experimentarla, pues ella es un producto vivo y humano. Tal es lo que hace el hombre de carne y hueso: "soy un mito que me voy haciendo día a día, según voy llevado al mañana, al abismo, de espaldas al porvenir. Y mi obra es hacer mi mito, es hacerme a mí mismo como mito. Que es el fin de la vida hacerse un alma[... ${ }^{\prime 31}$.

Esta es una de las preclaras proclamas del existencialismo, el hombre no nace, sino que se hace, lo cual cobra vida si se trata de la

${ }^{28}$ M. de Unamuno, O. C., Verdad y vida, Edición digital: Ediciones de la Fundación J. A. de Castro (2007): Ensayos, Artículos, Conferencias. Madrid, vol. IX, p. 826.

${ }^{29}$ M. de Unamuno, O. C., Vida de Don Quijote, op. cit. p. 231.

${ }^{30}$ M. de Unamuno, O. C., Contra el purismo, Edición digital: Ediciones de la Fundación J. A. de Castro (2007): Ensayos. Madrid, vol. VIII, p. 524.

${ }^{31}$ M. de Unamuno, O. C., Rosario de sonetos líricos, Edición digital: Ediciones de la Fundación J. A. de Castro (2004): Poesías, y otros. Madrid, vol. IV. p. 375. 
verdad humana. Estos dos autores quisieron hacer ese hombre con más piel sensitiva y voluptuosidad, con más hambre metafísica de absoluto que no de pura razón. Es una posibilidad que nos ofrece la lectura de Unamuno y Kazantzakis en conjunto, la de ser voces en protesta ante el reinado de la racionalidad y de la fe tradicional, de la razón y fe como discursos excluyentes y autocentrados que no encarnan la auténtica hambre mística y hambre metafísica del hombre de carne y hueso.

\section{Unamuno, Kazantzakis, ecos de un giro antropológico}

En todo tiempo se han planteado importantes cuestiones filosóficas, preguntas radicales y al límite, dándose así inicio a cursos de exploración estrechamente vinculados al hombre, al mundo y a un supuesto Dios o dioses. A la manera propia de cada uno de estos inquietos espíritus, se logra ver que ellos pusieron un esfuerzo en volver a poner en circulación intelectual las viejas preguntas de la humanidad, pero sin esa sistematicidad buscada por las disciplinas. No queda claro si lograron en última instancia confeccionar una cosmovisión propia de eslabones, piezas y fuentes conocidas, porque entendemos más bien que suyo fue el gesto de replantear esas inquietudes dentro de un pensamiento poético filosófico y natural en tales autores. Para ellos estaba claro que tanto la filosofía tradicional con su variedad de ismos como la razón excluyente de otras manifestaciones del espíritu humano, han caído en sospecha, en cuestionamientos de haber olvidado al hombre como tal, y de ahí que sea necesario un giro antropológico. De modo que para estos autores, el salmantino y el cretense, no sólo hubo un Deus absconditus sino que también se halla un homo absconditus que las ciencias y los discursos de la fe o la razón hegemónica pasaron por alto. Junto al pregonero trágico de Unamuno, también Kazantzakis muestra una desconfianza ante las visiones que pretenden encerrar al hombre dentro de una pulcras paredes de laboratorio o de una Biblia. El dios cristiano al que aluden varias obras del autor cretense -pero que crudamente Comedia silencia de modo dramático--, tampoco presenta la necesidad de ser reemplazado por otro dios que no sea el propio hombre. 
En el grito de Nietzsche donde se decreta la inapelable "muerte de Dios", Kazantzakis leerá ahí dentro de esa misma crisis de valores una especie de llamamiento a la liberación, verá el fruto de una necesaria proeza de aceptación de la vida tal como es, y también de una vida en contradicciones consigo misma en el sentido unamuniano de una razón que lucha con la pasión, con el sentimiento trágico, con la voluntad humana de "conocer" la realidad sintiéndola, saboreándola de modo interior, vitalmente, dionisíacamante. Es filosóficamente una liberación de ese frío discurrir conceptual, kantiano, positivista. Esa muerte pregonada por el filósofo alemán es el paso que falta para que el hombre pueda y se atreva a decir esto es lo que quiero: libertad, transubstanciación, ascensión en el caso de Kazantzakis, eternidad, sentido trágico y sentimiento existencial en Unamuno; y un mundo de superhombres y dionisismo para la tierra, en Nietzsche. A partir de toda una tonalidad nihilística-trágica, o mediante el desarraigo, el sentimiento de extranjeridad, el vértigo existencial, la perplejidad del mundo, la incertidumbre vital, la libertad de ser el centro de la propia existencia, de la ruptura teológica y de la esperanza abierta al tiempo que se vuelve vacío, uno puede intuir la orquestación que adquieren estas obras oscilantes entre literatura y filosofía -Comedia en Kazantzakis, Del sentimiento trágico en Unamuno y Así habló Zaratustra en Nietzsche- y que en su trasfondo recogen ese llamado nietzscheano por la emancipación de los dogmas, de la razón no sintiente, de los discursos logocéntricos-totalizantes, y que apuestan por un vivir peligroso y afirmativamente lo que sea la vida. Tras el horror de la agonía unamunesca ante lo que sea que es la muerte propia, o de la búsqueda de salvación que haga del hombre un ser libre y sin temores, de la actitud vitalista por eternizar la vivencia humana en el lugar donde está el hombre de carne y hueso, tras el estoicismo kazantzakista por vencerse a sí mismo, o la superación del propio hombre como punto de partida en el nietzscheísmo, tras todo este tipo de planteamientos y linealidades filosóficas, uno los contemplaría como un grupo aparte, bajo un pensamiento atrevido para la tradición filosófica como tal, inaugurando lo que sería la llegada de la aurora de los "espíritus libres" de Nietzsche: 
"Nosotros "espíritus libres", vivimos solitarios aquí y allá sobre la tierra -poca variación admite esto: somos en número escaso--, $y$ es justo que así sea. Corresponde a nuestro orgullo pensar que nuestro estilo es un estilo "raro" y "extraño", y no nos apiñamos los unos con los otros, acaso no "deseamos" siquiera encontrarnos con otros. Ciertamente: si acaso nos encontramos, como hoy, es para nosotros un día de fiesta. Si empleamos la palabra "felicidad" en el sentido de nuestra filosofía, no queremos designar con ella (como hacen los cansados, los angustiados y los que sufren) a la paz interior o exterior, o la ausencia de dolor, o la inmovilidad, o la imperturbabilidad, o un "sábado de los sábados", o una situación de equilibrio, o cosa equivalente a un profundo sueño sin ensueños. Nuestro mundo, acaso un mundo peligroso, es todo aquello que es incierto, mudable, capaz de transformación, múltiple; y es ciertamente más peligroso que el mundo simple, siempre igual a sí mismo, calculable, fijo, al cual hasta ahora los filósofos, como herederos de la felicidad del rebaño y del terror del rebaño, rindieron los más altos honores”.

Ante lo que el filósofo alemán denuncia como una vida humana temerosa de las incertidumbres y que busca el sentido de lo que sea vivir arrastrándose sobre una tierra segura, conocida, repetitiva, racionalmente iluminada, es que una obra como la de Comedia en Kazantzakis, más las temáticas unamunescas del más desesperado de los escritores españoles, aparecen como demonios para desenmascarar las viejas tablas de las verdades, de los dogmas, y tanto la razón como la fe son cuestionados de raíz, para que el hombre vuelva otra vez a la orfandad de sí mismo. Estas dos obras puntuales, Comedia y Del sentimiento trágico, surge aquilatarlas en conjunción de dos palabras: comedia y tragedia. Una comedia e impotencia de la razón -algo tan denunciado por Unamuno--, una comedia de las convenciones sociales y de la aparente estabilidad humana, por un lado; y por otro, una tragedia de la existencia humana, de la oscuridad vital y de la angustiosa sensación de no saber qué esperar de la vida y de la muerte. Unamuno va a plantear que la verdad "vitalista" es la que nos 
hace vivir en todo lo que somos, y eso significa declarar una especie de nueva verdad subjetiva, una verdad personal entre compromiso y responsabilidad consigo mismo. Será el fruto de ese dualismo entre razón y fe lo que llevará a Unamuno (muchas veces a Kazantzakis también) a seguir ese camino metarracional, el cual si bien no sabemos si satisface las demandas últimas del hombre al menos le permite vivir en la paradoja. Si para el unamunismo esa verdad vital, esa esperanza metafísica, esa expectativa de resolver el juego de la existencia misma es la que pasa a ser promotora del vivir, entonces, de alguna manera paradójica ocurre que esa misma verdad vital es la que hace morir a los personajes de Comedia, pues cada uno de ellos en el encierro de sus conciencias, justifican su tiempo de espera en base a lo que son sus creencias, a lo que fueron sus esperanzas más o menos religiosas, más simples en lo cotidiano o más ideológicamente elaboradas. En el universo unamuniano el sentido religioso es una puerta de acceso metafísico: "Lo que el hombre busca en la religión, en la fe religiosa, es salvar su propia individualidad, eternizarla, lo que no se consigue ni con la ciencia, ni con el arte, ni con la moral".

En el opúsculo dramático de Kazantzakis, Comedia, la idea de una lógica o de un esquema de creencias no parece esperable como argumentación, y lo que las escenas preludian más bien es que la voluntad humana está en un conflicto inexorable con las fuerzas de todo lo que es la vida misma, incluyendo las acciones de esa razón totalizadora. A su vez ese anhelo vital unamunesco de sentir quela vida humana marcha por una pendiente de futuridad, de permanencia, es una de las búsquedas de un rostro de dios para satisfacer ese afán metafísico de no perecer. Ambos autores han tomado esa metáfora de una sensación de falta de aire para respirar en el universo físico, expresando así el absurdo, el sentimiento de no pertenencia a nada, la aporía vital y, es precisamente ahí, en donde los contornos de la existencia humana adquiere esa velada dimensión de "situación límite" es que Comedia deja al descubierto.

Esta pieza del autor cretense deja una sensación apocalíptica en donde el Dios de las religiones, o el Dios de la fe tradicional, 
abandona al hombre sin más comunicación que el silencio místico, y en tal sentido, la obra abre una nueva dimensión. El personaje del Asceta proclama que su fe ha sido perfecta, impecable si la medimos de acuerdo a lo estipulado por la costumbre bíblica, y por lo tanto, no está dispuesto a aceptar tan fácilmente el silencio de Dios, es más, prefiere imprecarlo adrede con tal de que ese Dios de las religiones se manifieste, inclusive, bajo una cólera castigadora. El Asceta declama, ruega, grita, y hasta impreca lo impensable para un alma piadosa y sin embargo, no sucede nada, y en un momento de descontrol y de la pérdida total de la paciencia, pide que hasta un rayo del poder divino lo destruya en caso último. Así sucede con el homo religiosus, con el que quiere ver la visibilidad del Dios, con el que espera que suceda algo en medio de esas velas que se apagan bajo el silencio del mundo. Unamuno ha sentido esa misma interpelación en su poesía metafísica, y unos versos podrían interpretar al mismo personaje kazantzakiano del Asceta que ruega y protesta ante su Dios. El fondo emocional, vital, humano, desgarrador, es asombrosamente convergente y unos fragmentos unamunescos lo grafican:

"Una señal, Señor, una tan sólo,

una que acabe

con todos los ateos de la tierra;

una que dé sentido

a esta sombría vida que arrastramos"

Otra confesión filosófica, lírica, otra escena existencial que los conecta en el despliegue de una fe racional o religiosa puesta en crisis, es la que transcurre en la simbología de la puerta de entrada/ salida, la que en el caso de Comedia adquiere un rol dramático y dinámico en toda la obra. Recordemos que el Asceta se dirige a ese umbral, nos imaginamos su voz profética contra el muro, ante esa puerta que no se abre y que esconde lo que hay más allá. El Asceta de Kazantzakis pierde su cordura tratando de que las puertas caigan como las murallas de Jericó. Una imagen semejante aflora en el poeta español para una situación existencial extrema: 
"Dinos "yo soy", Señor, que te lo oigamos,

sin velo de misterio,

sin ningún misterio[...]

[...] yo te llamé, grité, lloré afligido,

te dí mis voces,

llamé y no abriste a mi agonía".

Estos dos autores, el griego y el español, viven la crisis de la fe, la falta de un consuelo confirmativo por encima del hombre, un qué visible para la razón común. Ese silencio, esas puertas cerradas o esos ruegos nos escuchados han sido el mayor corrosivo de la religión tradicional, una religiosidad que no da respuestas, sólo silencios y agonías. Las escenas por las cuales vamos viendo el avance de la agonía entre los doce personajes condenados en Comedia, y especialmente, lo que va sucediendo con el personaje eje símbolo de la obra, el Asceta, provoca una ruptura de nuestras creencias y miedos ancestrales más inamovibles que hemos recibido respecto de la fe, lo que preludia que la crítica religiosa debe ser llevada a un proceso de desmitificación. El hombre apegado a una escuela de fe tradicional ha de llegar entonces a su propia realidad interior gracias a esa orfandad de dioses, a las no respuestas de la razón, o por medio del nihilismo que actúa como corrosivo ideológico.

Kazantzakis ha puesto en esta obra varios acentos, la bancarrota de la racionalidad, de la razón ilustrada, la bancarrota en los mitos personales que se nutren del miedo y de una fácil esperanza, y el descrédito de las creencias religiosas tradicionales. Los personajes de Comedia van destejiendo sus cosmovisiones, y algunos de ellos afirmarán que buscaron el sentido de la vida por los caminos del conocimiento, de los libros, pero sin encontrar el qué de la vida. Centrales son esas escenas, como ya se ha dicho, en donde el personaje Asceta hará alarde de sus afirmaciones y dogmas. Pero sus conceptos de la fe, a medida que transcurre el tiempo y la espera como salvación que da respuestas al fenómeno humano, comienzan 
a socavarse en su optimismo ciego, heterónomo. Y va a ser el propio asceta, quien obligado ante sus acompañantes, el que deberá defender sus puntos de vista teológicos. La audiencia que en un principio escucha, ahora reflexiona así, “iy si Dios no viene!”. Emerge con esto una perspectiva del abismo, un territorio de la "condicionalidad humana” en el que no hay respuestas. El asceta defenderá su postura dogmática, no dialógica de búsqueda, y entonces les dirá solemnemente a quienes dudan: “¡Vendrá, nos ha dado su palabra!”. En los términos de Unamuno, se podría imaginar que esa conjunción de afirmación versus condicionalidad, puede retratarse en una frase, "sí el alma humana es inmortal [...]". Sin embargo, el sí de esa posibilidad se vuelve noche oscura en Comedia, donde no hay vislumbres de una mínima certeza ni colectiva ni individual, que es lo único real. Se oye decir al asceta que su dios ha prometido venir,,, Aún cuando lo dijera con humildad religiosa, no será ese el rumbo que tomará su frágil fe, una fe demasiado humana, según el decir nietzscheano. Queda así abierta la agonía, la tragedia que se develará como el acto humano por excelencia y que se experimenta como fuerza arrebatadora del destino. Unamuno nos dirá que "el sí es la huella que roe la rotunda voluntad humana de inmortalidad, es el termes que mastica la médula del árbol enhiesto de nuestra fe, es el sentimiento trágico de la vida". En el fondo de Comedia, se puede contemplar la ilustración unamunesca de los individuos sintiéndose a sí mismos como hombres vulnerables, que palpan su propia vida rodeada de finitud, lo cual pone en evidencia que ni la observación racional de los hechos ni la conciencia religiosa tradicional, son luces suficientemente esclarecedoras de la finalidad de los actos humanos.

Unamuno, con su estilo especulativo, agonista, sin haber conocido la obra del autor griego, formulará aporías y dudas que comparten el trasfondo dramático y existencialista de las visiones kazantzakianas en Comedia. He aquí unas coincidenciales palabras del escritor español que podrían prologar esta obra: “¿De dónde vengo yo y de dónde viene el mundo en que vivo y del cual vivo [...]?”. 
Asimismo, tenemos dos fragmentos que no hacen más que poner de relieve las inquietudes y el talante visceral, existencial y trágico que mueve a estos autores tan cercanos en sensibilidad. Se trata de enigmáticas visiones que perfectamente podrían ser el prólogo y esa voz en primera persona de quien se dispone a enfrentar la nada.

\section{Dice Unamuno:}

"Recógete, lector, en ti mismo, y figúrate un lento deshacerse de ti mismo, en que la luz se te apague, se te enmudezcan las cosas y no te den sonido, envolviéndote en silencio; se te escurra de bajo de los pies el piso, se te desvanezcan como en desmayo los recuerdos, se te vaya disipando todo en nada, y disipándote también tú, y ni aún la conciencia de la nada te quede siquiera como fantástico agarradero de una sombra".

A su vez, Kazantzakis, en el preludio de su Comedia, nos sacude con unas palabras que simulan una visión dantesca que antecede al desarrollo mismo de la acción teatral:

"Esta comedia se representa en el cerebro del hombre a la hora de la agonía cuando el alma se eleva hacia la sublime y totalizante coronación de la vida. Miedos y esperanzas que pasaron semiinconsciente y borrosamente y sólo rozaron la mente del hombre cuando ésta vivía - y después se olvidaron y se adormecieron despiertan ahora repentinamente en el momento de la muerte y se elevan con una intensidad de voz y de grito y de terror".

Por todo lo visto hasta ahora, se puede concluir que Kazantzakis y Unamuno van a ser unos autores contemporáneos en tiempo y divagaciones filosóficas, escritores de una misma época que se van a emparentar por una temática y una sensibilidad del hundimiento humano, por indagar en una situación existencial y tratar de filosofar en primera persona, sin olvidarse de su propia humanidad, por mesurar dramáticamente la gran confianza que se tenía en la ciencia y en la razón a comienzos del siglo XX. Todo ello como parte del giro antropológico. 
En estos autores, en el amplio grueso de sus obras, obras de todo aliento y tipo de género, se encuentra una fisonomía esencial tematizada en aspectos puntuales: hay una poesía metafísica, un discurso más expresivo que argumental; reflejan la vulnerabilidad humana que busca un sentido para la vida, y por eso a veces es una búsqueda desesperada; comparten alusiones a la soledad y a la disputa interna de las contradicciones del hombre que busca saber; la filosofía como oráculo que persigue enigmas, la necesidad de que el lenguaje sea mucho más que un "frío discurrir de intelecto" humano; un filosofar que no desprecie al "hombre de carne y hueso", una dramaticidad en torno al silencio de Dios, al Deus absconditus y a un homo absconditus. Tales son experiencias no prohibidas; la vida presentida como una peregrinatio vitae, como un desarrollo de cuestionamientos personales que marcan un peso existencial en lo que no es un simple decurso temporal. Son autores que llevan la angustia de la inmortalidad humana en sus escritos, y tienden a desconfiar de la religión tradicional, a la que de vez en cuando mitologizan o desmitologizan para sus propios fines filosóficos y creativos.

En referencia a todo lo anteriormente propuesto en una trama de elementos unamunescos y kazantzakianos, hemos mencionado a Comedia, una obra de factura controversial, rupturista y enigmática, en parte para decantar la cabida que hay en ella de elementos que circulan transversalmente por la obra del escritor español. También en parte para colindar dos sensibilidades que han sido vistas como las de "pensadores heterodoxos" que no se excluyen mutuamente, sino porque más bien dan la impresión de transitar en mundos paralelos. Asimismo, para ilustrar lo contrario, esto es, la lectura que cada uno haría de lo que puede haber de unamunesco en el horizonte de Kazantzakis, nada parece mejor que acompañarse de unos versos finales de Unamuno, los que podrían ir en el epílogo de Comedia: 
"La oración del ateo

Oye mi ruego Tú, Dios que no existes, y en tu nada recoge estas mis quejas,

Tú que a los pobres hombres nunca dejas sin consuelo de engaño. No resistes a nuestro ruego y nuestro anhelo vistes.

Cuando Tú de mi mente más te alejas, más recuerdo las plácidas consejas con que mi alma endulzóme noches tristes. ¡Qué grande eres, mi Dios! Eres tan grande que no eres sino Idea; es muy angosta la realidad por mucho que se expande para abarcarte. Sufro yo a tu costa, Dios no existente, pues si Tú existieras existiría yo también de verás". 


\section{Bibliografía}

Allen. E. (1953). Existentialism from Within, New York: Macmillan.

Antonio Pérez Rioja, J. (1977). Diccionario Literario Universal. Madrid: Editorial Tecnos.

Drandakis, P. (1930). Gran Enciclopedia Griega. Atenas: Editorial Fénix, $2^{\mathrm{a}}$ edición,

YALURAKIs, M. (1968). "Kazantzakis". Gran Enciclopedia de la Literatura Neohelénica. Del siglo X hasta hoy, tomo vii. Editorial Jaris Patsis: Atenas.

Ferrater M. J. (1944). Unamuno, bosquejo de una filosofía. Buenos Aires: Losada.

García Álvarez. C. (1997). Byzantion Nea Hellás, "Dos itinerarios espirituales: Miguel de Unamuno y Kazantzakis". Santiago: LOM Editores, $n^{\circ} 16$.

Hirschberger. J. (1990). Historia de la Filosofia. Barcelona: Editorial Herder.

KaHLER, E. (1960). Historia Universal del hombre, México: FCE.

Kazantzakis, N. (1968). Carta al Greco, O.S. Barcelona: Planeta, vol.. III. Kazantzakis, N. (2012). Comedia tragedia en un acto. Trad. Roberto Quiroz Pizarro. En Destino y fatalidad en dos dramas juveniles de Kazantzakis. Santiago: Centro de Estudios Griegos Bizantinos y Neohelénicos.

Kazantzakis, N. (2012). El primer maestro. Trad. Miguel Castillo Didier.

En Destino y fatalidad en dos dramas juveniles de Kazantzakis.

Santiago: Centro de Estudios Griegos Bizantinos y Neohelénicos

Kazantzakis, N. (1985). España dos rostros. Trad. Joaquín Maestre. Buenos Aires: Ediciones Carlos Lohlé.

Kazantzakis, N. (1998). Viajando España. Trad. Guadalupe Flores L. Madrid: Ediciones Clásicas.

Machado, A. (1949). Juan de Mairena. Buenos Aires: Losada.

Marías, J. (1959). La escuela de Madrid. Madrid: Revista de Occidente 
MARías, J. El existencialismo en España (versión digital)

Quiroz Pizarro, R. (2003). Nikos Kazantzakis Impromptu filosófico. Santiago: Centro de Estudios Griegos Bizantinos y Neohelémnicos.

Unamuno, M. (2007). O. C., Contra el purismo. Edición digital: Madrid: Ediciones de la Fundación J. A. de Castro (2007): Ensayos. vol. VIII.

Unamuno, M. (1913). Del sentimiento trágico de la vida, Madrid: Renacimiento.

Unamuno, M. (2007). O. C., En torno al casticismo. Edición digital: Madrid: Ediciones de la Fundación J. A. de Castro (2007): Ensayos. vol. VIII.

Unamuno, M. (2007). O. C. Mi religión y otros ensayos breves. Edición digital: Madrid: Ediciones de la Fundación J. A. de Castro (2007): Ensayos, Artículos, Conferencias. vol. IX.

Unamuno, M. (1999). O. C. Rosario de sonetos líricos. Edición digital. Madrid: Ediciones de la Fundación J. A. de Castro. Poesías, y otros, vol. IV.

Unamuno, M. (2007). O. C. ¿Qué es verdad? Edición digital. Madrid: Ediciones de la Fundación J. A. de Castro, vol. VIII.

Unamuno, M. (2007). O. C. Soliloquios y conversaciones. Edición digital: Madrid: Ediciones de la Fundación J. A. de Castro (2007): Ensayos, Artículos, Conferencias. vol. IX.

Unamuno, M. (2007). O. C. Verdad y vida. Edición digital: Madrid: Ediciones de la Fundación J. A. de Castro (2007). Ensayos, Artículos, CONFERENCIAS. VOL. IX.

Unamuno, M. O. (2006). O. C. Vida de Don Quijote. Edición digital. Madrid: Ediciones de la Fundación J. A. de Castro, vol. X. 